\title{
Kajian Penggunaan Ruang dan Kesehatan Lingkungan Suku Saga di Kabupaten Ende
}

\author{
Irawan Setyabudi ${ }^{1}$, Kristoforus Wasa Ngama ${ }^{2}$, Wahidyanti Rahayu Hastutiningtyas ${ }^{3}$ \\ 1,2 Fakultas Pertanian, Universitas Tribhuwana Tunggadewi \\ ${ }^{3}$ Fakultas Ilmu Kesehatan, Universitas Tribhuwana Tunggadewi \\ isetyabudi.st@gmail.com
}

\begin{abstract}
ABSTRAK
Desa Saga, Kabupaten Ende, Nusa Tengara Timur memiliki keunikan berupa rumah tradisional yang menjadi ciri khasnya, yaitu Sa'o. Tidak seperti rumah tradisional biasa, Sa'o memiliki ketua adat di setiap rumahnya. Fungsi rumah tidak hanya untuk tempat tinggal, tetapi menunjukkan hirarki sosial. Secara visual, bentuk dasar denah rumah adat berupa persegi dengan sudut atap yang sangat curam sehingga ikon atap terlihat dengan jelas. Filosofinya mengikuti analogi raga manusia, yaitu, lewu (pedestal/kaki), one (dinding/badan), gara (atap/kepala). Dalam lingkup makro, pola permukiman suku Saga mengikuti pola kontur, terdapat sekitar 20 rumah dengan tipologi yang sama. Permasalahannya adalah belum terdapat identifikasi penggunaan ruang pada aktivitas budaya. Selain itu, posisi lanskap berkontur tanpa naungan dan dikelilingi hutan memiliki kerentanan terhadap beberapa penyakit, serta belum terjelaskan keterkaitan antara penggunaan ruang dan kesehatan lingkungan. Meneruskan dari penelitian terdahulu yang membahas tentang kosmologi ruang, kajian secara mikro pada studi ini berhubungan dengan identifikasi fisik visual rumah adat, sedangkan dalam aspek makro dibahas penggunaan ruang untuk aktivitas budaya serta aspek kesehatan lingkungannya. Metode pencarian data dilaksanakan dengan diskusi kelompok terarah (FGD) dan metode analisisnya dilakukan secara deskriptif kualitatif dengan pendekatan etnografi. Hasil penelitian ini berupa deskripsi mengenai ruang-ruang yang digunakan untuk aktivitas budaya pada ruang dan waktu tertentu serta upaya peningkatan kesehatan lingkungan masyarakat. Kesimpulannya, bahwa masyarakat suku Saga memiliki kearifan lokal dalam hal arsitektur tradisionalnya, selain itu sisi intangible berupa tradisi yang diwariskan dan upaya peningkatan kesehatan lingkungan.
\end{abstract}

Kata kunci: ruang, arsitektur tradisional, aktivitas, kesehatan lingkungan

\section{ABSTRACT}

Saga Village, Ende Regency, East Nusa Tenggara has a traditional house that becomes its identity, namely Sa'o. Unlike ordinary traditional houses, Sa'o has a customary leader in each house. Thus, the house is not just a place to live but also shows the social hierarchy. Visually, the floor plan is a square with a very steep roof angle so that the roof is visible. The philosophy follows the analogy of the human body, that is, lewu (pedestal/ foot), one (wall/ body), gara (roof/ head). On the macro scale, the Saga settlement pattern follows the contour pattern. There are about 20 houses with the same typology. The use of space in cultural activities is not yet identified. Besides, the position of the contoured landscape without shade and surrounded by forests has a vulnerability to several diseases. The link between space use and environmental health also has not yet been explained. Continuing from previous research on space cosmology, the micro aspect in this study deals with the physical identification of traditional houses. In contrast, in the macro aspect, it discusses the use of space for cultural activities and aspects of environmental health. The data collection was carried out through focus group discussions (FGD) and analyzed using a descriptive qualitative method with an ethnographic approach. The results of this study are descriptions of spaces used for cultural activities at a particular time and place as well as efforts to 
improve public environmental health. In conclusion, Saga people have local wisdom in terms of traditional architecture, in addition to the intangible form of inherited traditions and efforts to improve environmental health.

Keywords: space, traditional architecture, activity, environmental health

\section{Pendahuluan}

Nusantara memiliki kekayaan alam dan budaya yang sangat beragam, salah satunya adalah bentuk arsitektur tradisionalnya. Bangunan ini dikenali dengan bentuk yang mewakili kekhasan masing-masing daerah sehingga menjadi identitas suatu daerah. Selain itu dalam segi struktur, konstruksi, dan proses pembuatannya. Rumah tradisional dibangun tanpa cara yang kaku seperti dokumen formal, namun dari kebiasaan dan memiliki tipologi yang sama dengan kecenderungan adanya perubahan. Sedikit berbeda dengan rumah tradisional, rumah adat memiliki nilai yang lebih tinggi seperti tingkat kesakralannya dan tingkat keasliannya. Rumah adat berfungsi sebagai hunian bagi suku bangsa tertentu dan sebagai penanda utama bagi perkembangan peradaban masyarakat. Sampai saat ini, banyak suku-suku yang berupaya mempertahankan rumah adat sebagai warisan nilai budaya (Said, 2004). Salah satu alasan dilakukannya penelitian ini adalah ragam bentuk rumah adat perlu ditunjang dengan kajian yang bisa memberikan pengetahuan yang bermanfaat untuk masyarakat (Pramono, 2017).

Rumah adat merupakan ciri khas bangunan suatu etnik dalam wilayah tertentu. Masing-masing daerah memiliki keragaman dan kekayaan budaya. Begitupula rumah adat yang terletak di Desa Adat Saga, Kabupaten Ende. Upaya pelestarian telah dilakukan agar rumah adat tetap terjaga keasliannya dan dilestarikan. Salah satunya dengan merenovasi beberapa bagian rumah yang sudah rapuh. Kebanyakan rumah adat di nusantara menggunakan material ringan (dari kayu), dan dengan konsep ruang untuk bernaung; bukan berlindung; sehingga dalam timeline tertentu rumah harus direnovasi. Berbeda dengan daerah dengan kondisi ekstrim di subtropis, dengan konsep ruang berlindung, yakni dengan material yang lebih tebal. Pengetahuan tentang cara pendirian rumah adat diturunkan dengan knowledge transfer dan bukan tekstual, sehingga jika warisannya putus, maka putus juga pengetahuannya. Belajar dari pengalaman arsitek Yori Antar di tahun 2008-2016 yang pernah dipresentasikan di InSAN 2017, rekonstruksi rumah adat dilakukan di Waerebo, berawal dari cerita yang diberikan secara turuntemurun, direkonstruksi secara partisipatorik bersama masyarakat, berpotensi menjadi daerah wisata budaya dan akhirnya menjadi ikon daerah. Analogi dari peristiwa tersebut dapat menjadi tambahan pengetahuan untuk desa adat Saga.

Di desa Saga, terdapat Sa'o, yaitu rumah adat sebagai tempat tinggal dalam melakukan aktivitas sehari-hari bagi masyarakat. Ada tipologi yang sama baik susunan ruang dalamnya maupun bentuk selubung luar rumahnya dalam satu kawasan. Rumah berada pada lahan berkontur; seperti terasering; dengan massa terpisah antara rumah satu dengan yang lainnya. Satu rumah umumnya dihuni empat orang, kecuali rumah besar yang dihuni secara komunal oleh dua belas orang. Ruang sakral berada di depan masing-masing rumah, yang mana ada makam leluhur, dan tidak diperbolehkan adanya pohon di sekitar rumah.

Penelitian ini mendesak dilakukan karena ada kekhawatiran tentang eksistensi rumah adat saga, yang mana seiring majunya jaman akan menyebabkan kepunahan terhadap rumah adat dan tradisinya, sehingga kehilangan identitas, mengingat setelah terjadinya peristiwa gempa permukiman adat sekarang juga hasil rekonstruksi dari permukiman sebelumnya, serta berbatasan dengan desa yang rumahnya lebih modern. Melanjutkan penelitian sebelumnya yang membahas tentang kosmologi ruang oleh 
Achmad, et al. (2017), permasalahan kajian ini adalah bagaimana identifikasi ruang rumah tinggal secara mikro dan lingkungannya secara makro untuk aktivitas budaya? Selain itu, bagaimana keterkaitan pola penggunaan ruang untuk kesehatan lingkungan? Kebaruan bahasan yang didapatkan yaitu posisi rumah ternyata memiliki sistem pasif yang menyehatkan penghuni, serta tanaman sekeliling rumah selain untuk kebutuhan sehari-hari, juga untuk obat dan berperan untuk ritual tertentu dalam konteks ruang makro.

\section{Bahan dan Metode}

\subsection{Bahan Kajian Literatur}

(a) Rumah Adat

Rumah adat menurut Said (2004) adalah suatu bangunan yang mempunyai karakteristik tertentu, berfungsi sebagai hunian oleh suku tertentu. Hal ini diperkuat oleh Pramono (2017) yang juga menyatakan bangunan dari suatu daerah yang melambangkan budaya dan ciri khas masyarakat setempat. Rumah adat sebagai bukti yang mewakili kebudayaan tertinggi dari suatu komunitas suku. Eksistensinya sangat bervariasi dan memberikan makna penting dalam tolok ukur sejarah dan peradaban masyarakat. Rumah adat beserta lingkungannya diulas dari sisi penggunaan ruangnya.

\section{(b) Penggunaan Ruang}

Ching (2014) menyatakan secara visual eksistensi suatu ruang yang mana diawali oleh titik, membentuk garis, membentuk bidang, dan akhirnya terbentuklah ruang. Dengan demikian ruang adalah dimensi tiga terukur. Di sisi lain, Prijotomo dan Pangarsa (2010) menyatakan bahwa ruang adalah suatu kehadiran, adanya aktivitas manusia dalam suatu wadah. Jadi tanpa adanya aktivitas, ruang hanyalah tempat yang tidak bermakna. Kaitannya dengan permukiman tradisional, ruang adalah tempat yang memiliki nilai positif karena digunakan untuk aktivitas budaya, selain secara visual dibentuk oleh arsitektur yang unik dan menarik.

\section{(c) Aktivitas Budaya}

Budaya dari bahasa sansekerta yaitu buddhayah, bentuk jamak dari buddhi (budi atau akal). (Koentjaraningrat, 2004). Kebudayaan berhubungan dengan segala aspek kehidupan, yang bermakna cara berlaku, kepercayaan dan sikap yang berasal dari aktivitas manusia yang khas dari masyarakat atau kelompok tertentu. Aktivitas budaya dalam hal ini merupakan hubungan antara budaya dan penggunaan ruang tertentu pada masyarakat, baik mikro maupun makro, terkait dengan aspek kesehatan lingkungan.

\section{(d) Kesehatan Lingkungan}

Keseimbangan antara lingkungan dan manusia, sehingga dapat tercapai kondisi yang bersih aman, nyaman, sehat dan dijauhkan dari berbagai jenis penyakit. Hubungannya adalah suatu permukiman tradisional yang berada di sekitar hutan, kondisi masih alami, perlu dikaji dari sisi responnya terhadap kesehatan masyarakat. Menurut Undang-undang no. 23 tahun 1992 tentang kesehatan ada beberapa ruang lingkupnya, tetapi dalam kajian ini hanya dibatasi dari sisi upaya pencegahan terhadap penyakit. Pencegahan penyakit dilakukan dengan melihat sisi penyehatan air dan udara, pengamanan limbah padat/sampah, pengamanan limbah cair dan pengamanan limbah gas. Upaya dicapai dengan penanaman pada lahan kosong dan penyesuaian posisi ruang, baik penataan ruang dalam dan tata massa bangunan. 


\subsection{Metode Penelitian}

Metode penelitian dilakukan secara deskriptif kualitatif dengan pendekatan etnografi. Data dikumpulkan sesuai dengan keadaan sesungguhnya secara kualitatif atas fenomena yang terjadi pada masyarakat. Proses berikutnya dijabarkan secara deskriptif untuk mendapatkan gambaran dan kesimpulan yang menjawab permasalahan penelitian. Pendekatan Etnografi dipilih karena mempelajari kejadian kultural, sajian pandangan hidup objek studi. budaya Suku Saga, sehingga juga diketahui pola ruang untuk aktivitas budayanya. Berdasarkan metode etnografi dari Creswell \& Poth (2016). Etnografi diperkaya dengan memasukkan setting waktu dan teritori kegiatan. Penggunaan ruang dibagi menjadi kegiatan yang sifatnya rutin/ harian, periodik (bulanan/ tahunan/ musiman) dan event/ peristiwa tertentu. Penggunaan ruang dijelaskan dengan konteks waktu dan perubahan batas ruangnya. Sejalan dengan metode penelitian yang telah dilakukan oleh Indeswari, et al. (2013) dan Fitriyani, et al. (2015).

Penelitian ini diawali dengan pengamatan langsung di lapangan yang dibuktikan dengan data fisik (foto, sketsa, dan hasil survey), data wawancara didapatkan melalui diskusi kelompok terarah/ focus grup discussion. Paramita \& Kristiana (2013) menyebutkan bahwa FGD adalah teknik pengumpulan data kualitatif untuk menggali informasi persepsi masyarakat. Data yang didapatkan berupa informasi tentang fisik visual rumah tinggal beserta unsur ruang pembentuknya, seperti sejarah, dan budaya masyarakat. Deskripsi berupa gambaran mengenai bagaimana karakteristik rumah tradisional masyarakat Saga beserta penggunaan ruang yang diawali dengan identifikasi aktivitas budaya yang berhubungan dengan daur hidup. Perwujudan analisis deskripsi dibantu oleh software visualisasi yaitu Sketchup 2020 dan Autocad 2021. Behavioral mapping atau peta perilaku juga digambarkan untuk menunjukkan lokasi aktivitas berlangsung dan pergerakan perilaku dalam aktivitas tersebut. Bentuknya berupa diagram mengenai tempat manusia menjalankan aktivitasnya. Faktor yang menjadi pembentuk ruang yang digunakan bersama (shared space) adalah aktivitas, waktu dan tempat, sedangkan yang menjadi akibatnya adalah pola ruang bersama. Selain itu, berdasarkan hasil observasi daerah eksisting, dijabarkan potensi kesehatan lingkungan masyarakat, tentang bagaimana pengaruh lingkungan rumah adat terhadap kesehatan penghuninya. Terakhir, hasil identifikasi dianalisis berkaitan dengan hubungan arsitektur dan penggunaan ruangnya berdasarkan teori, sehingga diperoleh kesimpulan.

Objek penelitian berada pada permukiman adat suku Saga yang berada di Kabupaten Ende. Lokasi dipilih karena memiliki arsitektur dan budaya yang khas dan berbeda dengan daerah yang lainnya. Waktu penelitian di bulan Juni sampai dengan Juli 2019. Gambar 1 menunjukkan lokasi objek studi.

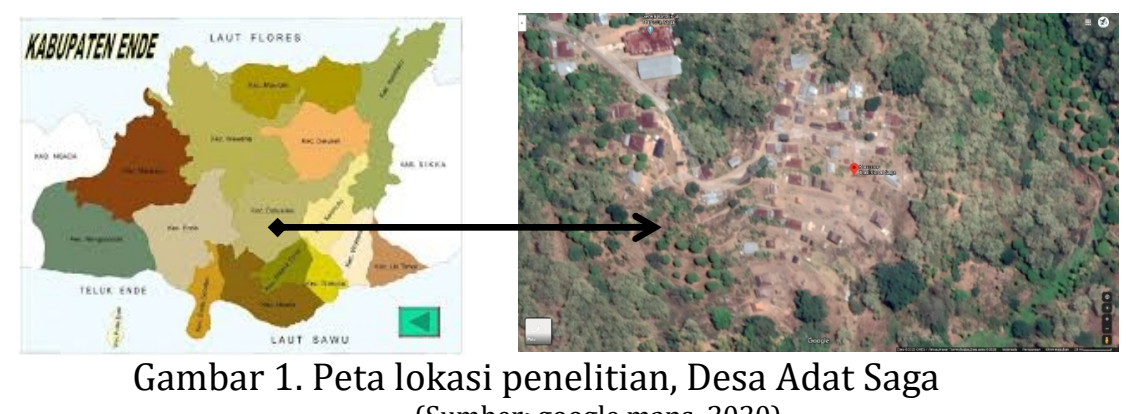

(Sumber: google maps, 2020) 


\section{Hasil dan Diskusi}

\subsection{Sejarah Permukiman}

Sebelumnya De Rosary (2016) dan diperkuat oleh Ahmad, et al. (2017) dalam penelitiannya menyebutkan bahwa kata Saga bisa di-breakdown dari unsur pembentuknya yaitu $S a$ (bunyi air) dan $G a$ (terpandang), berarti definisinya adalah suara yang berwibawa atau terhormat, atau secara tersirat dapat diartikan suara kesejukan, keberuntungan dan perdamaian. Nilai yang diturunkan secara tersirat terdapat warisan martabat kepemimpinan dari para pendahulu.

Desa Adat Saga terbentuk pada awal tahun 1900, lalu terjadi kerusakan oleh karena gempa bumi di tahun 1992 di pulau Flores. Di tahun 1993, rumah adat Saga direkonstruksi kembali pada lokasi yang berbeda, yaitu berada di bawah bukit yang tidak jauh dari lokasi sebelumnya (di atas bukit). Rekonstruksi kembali ini seperti yang diulas pada latar belakang kajian ini; analogi dari arsitek Yori Antar, namun dengan kasus yang berbeda. Morfologi dari awal pembangunannya hingga saat ini belum mengalami perubahan secara visual.

Desa Saga berbatasan dengan Desa Mboto yang terletak di sisi barat, yang terbagi atas dua lokasi yaitu Mboto Wena dan Mboto Wawo. Embu Wolo menempati Mboto Wena sedangkan Embu Limbu Menempati Mboto Wawo. Kedua Embu tersebut membangun desa secara bersama.

Dahulu, ada dua saudara yang mendiami desa adat Saga yaitu Dala Wolo dan adiknya, Labha Dile. Mereka membangun rumah yang dikenal sebagai Sa'o Nggua dan tinggal bersama. Semakin lama semakin banyak keluarga yang tinggal, sehingga Dala Mbele membangun Sa'o Nggua Ele Mblele sebagai rumah yang baru. Waktu itu Dala Wolo sudah membangun Tubu Musu dan Keda yang terletak di depan rumah adat, yang digunakan untuk upacara ritual. Setelah orang ini mendiami desa Saga, maka kedua Embu melakukan perjanjian dengan para pendahulu yang isinya masyarakat yang hidup di Mboto pindah ke desa adat Saga dan membangun desa secara bersama-sama. Perjanjian ini disebut dengan Nggo Nggoro Ngamba Kara. Masyarakat desa bekerja sama membangun desa sampai sekarang.

\subsection{Kondisi Eksisting}

Bentang alam Desa Saga terletak di lahan perbukitan dan berkontur dengan cukup tajam dan dikelilingi oleh hutan. Kontur mirip terasering yang ditahan oleh retaining wall dari tumpukan batu. Tidak ada vegetasi khusus yang berada di sekitar rumah hanya rumput dan alang-alang, hal ini karena lahan yang berada di depan rumah adat disakralkan yaitu terdapat makam para leluhur dengan ditandai oleh batu berbentuk persegi panjang (batu ceper). Foto penelitian diambil pada pertengahan tahun atau musim kemarau sehingga lanskapnya terlihat kering, hal ini kebalikannya jika diambil saat musim hujan yang tampak begitu hijau. Permukiman adat terdapat sekitar dua puluh rumah yang mana wajib dilestarikan, adapun yang berada di tepi permukiman adat sudah terdapat rumah-rumah dengan menggunakan material yang lebih modern. Hal yang cukup jelas adalah penggunaan atap seng, kontras dengan Sa'o yang masih menggunakan alang-alang. Pergeseran lainnya adalah penggunaan atap pelana, dinding, dan lantai sudah menapak tanah (bukan panggung lagi). Fasilitas umum berada pada permukiman ini seperti pendidikan, puskesmas dan tempat ibadah. Total penduduknya berjumlah 653 jiwa. 


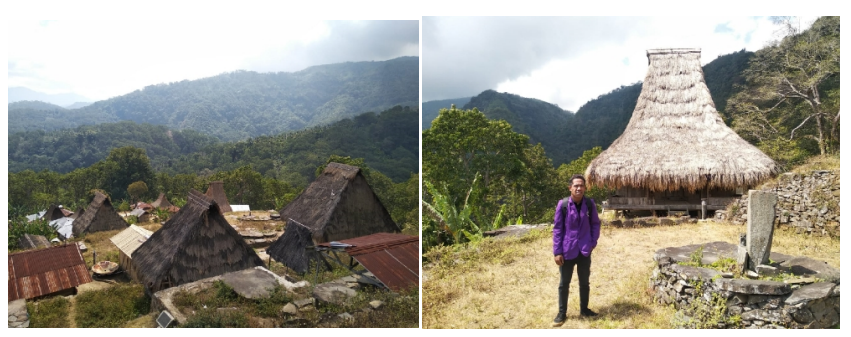

Gambar 2. Lokasi permukiman berada pada daerah berkontur (kiri), lokasi Tubu Musu sebagai episentrum kegiatan adat tarian gawi (kanan)

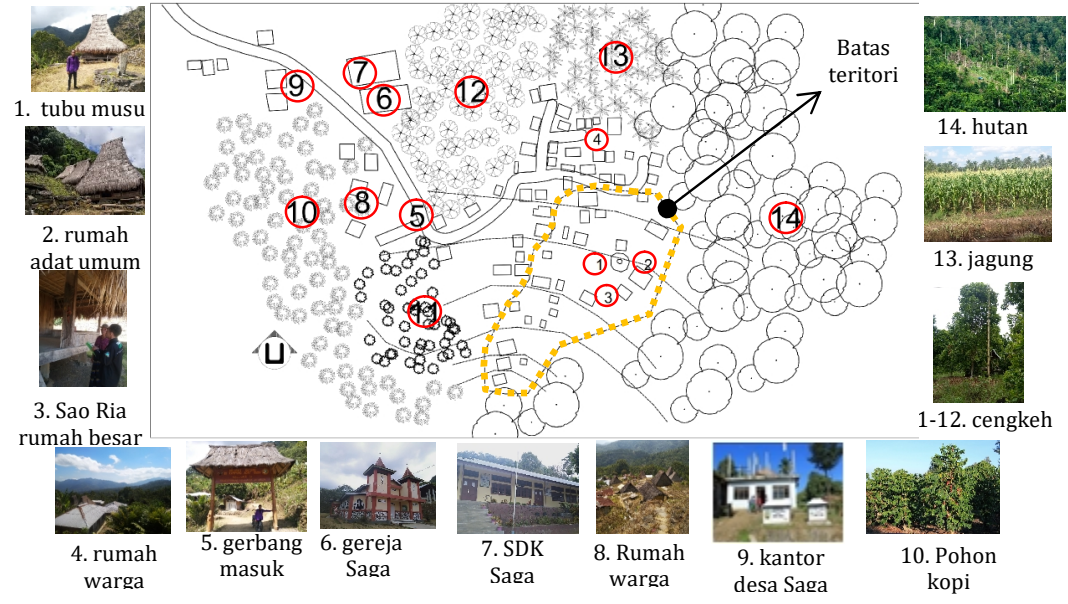

Gambar 3. Zona Desa Adat Saga

\subsection{Rumah Adat Saga}

Kajian diawali dalam lingkup mikro terlebih dahulu yang berkaitan dengan rumah adat desa Saga, yaitu Sa'o. Seperti yang telah dijelaskan oleh Ahmad, et. al.(2017). Tiap rumah adat terdapat ketua adat (mosalaki). Karakteristik rumah berbentuk persegi, dengan atap dengan sudut curam bisa sampai 7 meter, seluruh tiang, lantai, dinding, terbuat dari kayu. Berdasarkan filosofinya, makna atap ini berkaitan dengan kesatuan dengan sang ilahi. Puncak atap terdapat tiga tanda yaitu kola keda (kepala keda), kolo sa'o (kepala sa'o) dan saga wula leja (tiang altar matahari dan bulan). Sinergis dengan kepercayaan bahwa dunia terbagi menjadi tiga yaitu dunia bawah, tengah dan atas maka, analogi tubuh manusia : kaki, badan dan kepala.

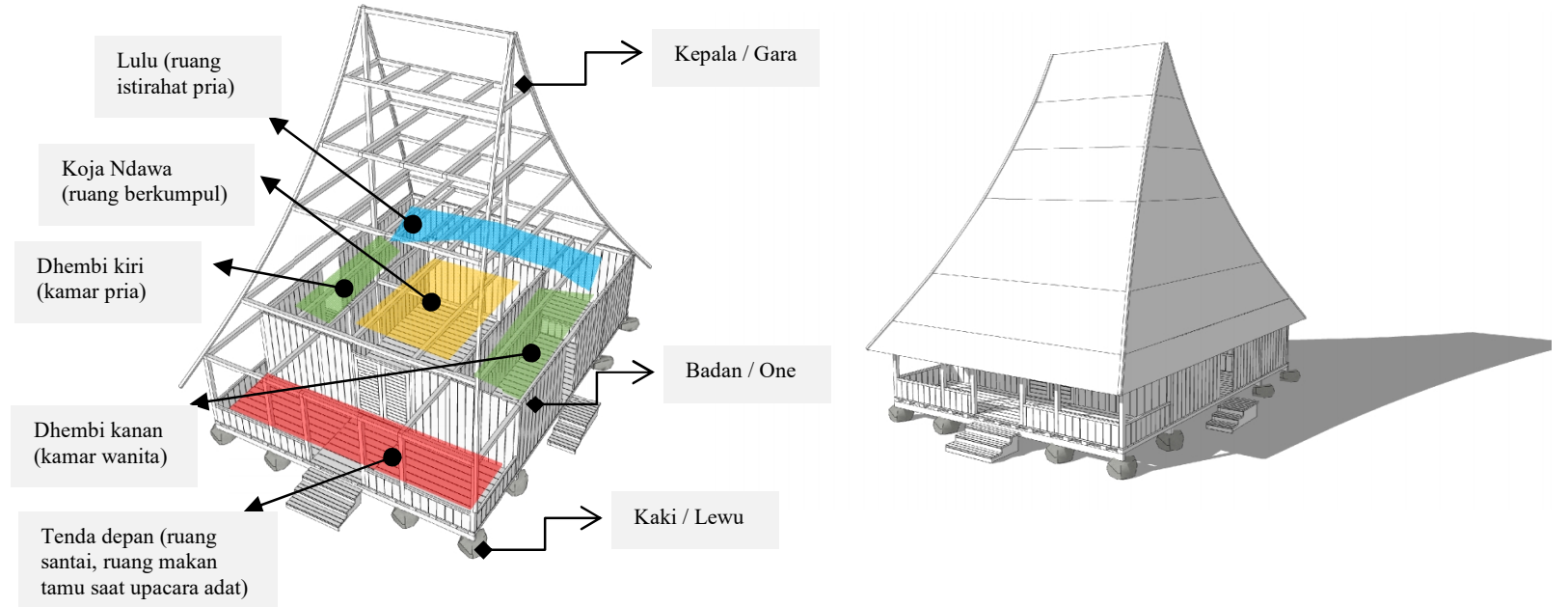

Gambar 4. Struktur dan ruang Sa'o (kiri), fasade Sa'o (kanan) 
Masih menurut Ahmad, et al. (2017) pembagian sistem vertikal rumah adat Sa'o sebagai berikut:

1) Bagian atas (gara) berfungsi sebagai penutup struktur rumah, dimaknai dengan kewibawaan dari ketua adat, suci, dan hubungannya dengan tuhan.

2) Bagian tengah (one) sebagai ruang untuk aktivitas keseharian seperti makan, masak dan tidur. Maknanya berhubungan dengan kehidupan yang harmonis

3) Bagian bawah (lewu) berfungsi untuk konstruksi penahan beban di atasnya. Maknanya dianggap sebagai bagian terendah dan kotor. Ruang bisa berfungsi untuk kandang hewan seperti ayam dan babi, yang sewaktu-waktu bisa untuk upacara adat.

Sedangkan pembagian ruang interior rumah adat Sa'o:

1) Bagian depan (tenda) berfungsi sebagai ruang tamu dan untuk bersantai.

2) Bagian samping (dhembi), wujudnya dhembi kanan sebagai ruang istirahat (kamar) perempuan, sedangkan sebelah kiri untuk pria

3) Bagian tengah (koja ndawa), merupakan area berkumpul dan bersama. Ruang ini merupakan inti sehingga disebut rahim sa'o

4) Bagian belakang (lulu), merupakan ruang istirahat pria. Wujudnya berupa ulu atau kepala, yang dimaknai kepala rumah tangga.

\subsection{Aktivitas Penggunaan Ruang}

Dari hasil pengamatan dan FGD, didapatkan pola aktivitas yang berkaitan dengan pemanfaatan ruang bersama di tingkat meso dan makro (lanskapnya). Aktivitas bersama berupa ucapan syukur atas keberhasilan panen padi yang disebut Nggua. Selain itu juga berhubungan dengan daur hidup yaitu upacara pernikahan, kelahiran, dan pemakaman.

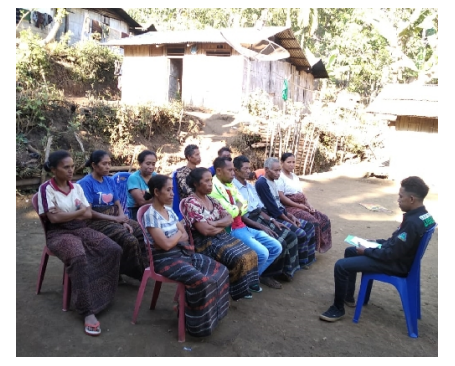

Gambar 5. Proses pencarian data dengan FGD oleh K. W. Ngama (kanan)

\section{1) Hasil Pengamatan Aktivitas Upacara Adat Syukuran Panen dan Tanam Padi}

Panen padi merupakan aktivitas rutin yang dilakukan secara periodik atau tahunan dengan menggunakan ruang bersama dilakukan pada bulan September. Pesta adat dilakukan sebagai upaya syukur atas keberhasilan panen padi. Urutan ritual $\mathrm{Nggua}$ adalah Uta Bue (menanam kacang), kemudian Uwi Keu Kana (menanam ubi) dan terakhir Keo (menanam pinang). Rangkaiannya dimulai sejak membuka ladang baru sampai ditutup dengan menari bersama pada saat pesta tersebut. Ritual ini dilakukan oleh ketua adat pada waktu pagi hari jam 8 sampai sore hari jam 4 di sawah.

Berdasarkan kutipan dari De Rosary (2016) dan diikuti pengamatan peneliti, ritual tanam padi diawali dengan menentukan lokasi lahan baru atau $S o A u$, selanjutnya dilakukan Ngeti (potong padi dengan pisau), Poto Ura Aje atau secara simbolis membuka huma yaitu dengan pembukaan ladang yang mana diikuti pantangan beberapa waktu. Sesudahnya, huma yang sudah kering dibakar lalu dijadikan kebun, dilanjutkan dengan upacara Seru Fata atau mencegah balak yang mana tanah dibungkus dengan ranting dan dahan lalu ditarik dari sisi atas menuju ke sisi lebih rendah dari kebun. Aktivitas tanam padi dilakukan pada bulan mei-juni pada pagi hari jam 8 sampai sore hari jam 4 . 
Proses berikutnya adalah Tedo atau menanam padi dan tanaman lainnya. Tedo pertama di pagi hari dilakukan oleh mosalaki, lalu disusul oleh masyarakat biasa. Sewaktu umur tanaman sudah tiga bulan dan mulai mendekati masa panen, dilakukan tonda lobo rabhe rara yang ditandai dengan makan kacang-kacangan. Adapun nilai-nilai yang dapat diambil adalah mengingatkan kembali keturunan dari leluhur, karena kacangkacangan buahnya bersusun yang dapat dimaknai keturunan yang tidak terhenti dan terus berlanjut.

Setelah siap panen, dilaksanakan keti pare atau padi dipetik dan disimpan dalam lumbung (bhengge). Upacara untuk memperingati hasil panen dilakukan dengan makan nasi baru atau Nggua Keu-Uwi (keu berarti pinang, sedangkan uwi adalah ubi). Berikutnya setelah acara makan bersama, juga dilakukan upacara tolak balak atau joko ju, yang dimaksudkan agar segala penyakit atau kesialan tidak terjadi saat membuka ladang baru, serta harapan hasilnya mencukupi bagi masyarakat.

Keesokan harinya ritual ditutup dengan gawi atau menari bersama yang diawali oleh para mosalaki dan diikuti masyarakatnya. Sebelum gawi dilakukan, mosalaki menuangkan arak dan memberi makan leluhur. Lokasinya berada di batu ceper/ tubu musu yang berada di tengah lapangan. Setelah itu hasil panen dibawa ke masing-masing rumah adat.

Jika disimpulkan, ada beberapa ruang bersama di tingkat makro yang digunakan yaitu ladang/sawah, lumbung, dan tubu musu/pelataran/batu ceper, sedangkan ruang mikro yaitu rumah adat. Untuk memudahkan dan meringkas proses di atas maka dijabarkan dalam bentuk ilustrasi gambar 6 .
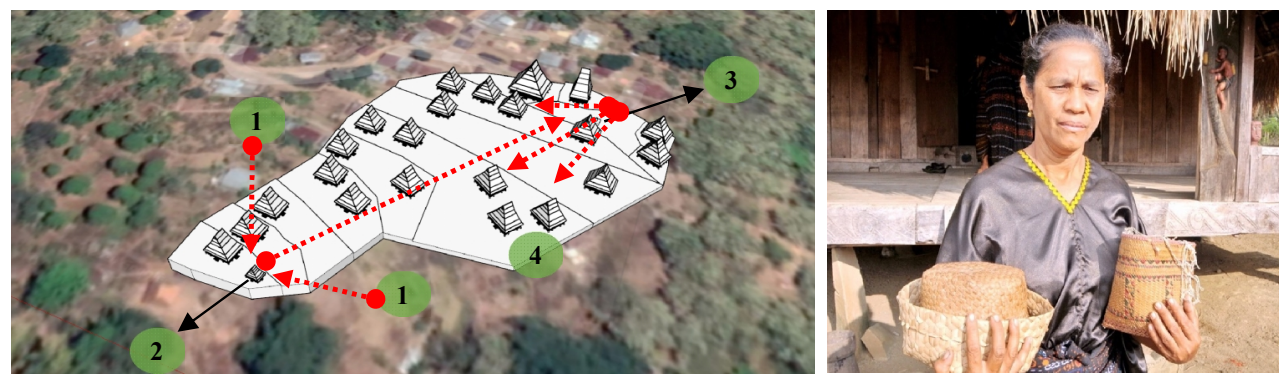

Gambar 6. Pemetaan aktivitas bersama saat upacara adat syukuran panen padi dengan tarian gawi bersama. [1] Ruang bersama fasilitas yaitu ladang/sawah tempat berlangsungnya upacara buka ladang dan panen, [2] Ruang bersama fasilitas yaitu lumbung padi, [3] Ruang bersama pelataran, tempat berlangsungnya gawi, [4] Rumah, hasil panen dibawa ke rumah

\section{2) Hasil Pengamatan Aktivitas Upacara Pernikahan}

Kegiatan ini berlangsung saat adanya acara tertentu atau tidak rutin, dengan menggunakan ruang skala meso/makro. Pernikahan atau Nika kawi terjadi saat pria dan wanita sudah menyelesaikan tahapan secara adat dan mendapat pengesahan dari agama katholik. Secara garis besar tahapan pesiapan antara lain mengikuti kursus persiapan, pemanggilan nama di gereja, pembinaan dan resepsi pernikahan dilakukan oleh pihak wanita.

Menjelang acara, pihak keluarga wanita menjamu makan sesepuh desa. Adapun maknanya yaitu permohonan ijin dan meminta dukungan dari para sesepuh atas kegiatan pernikahan yang akan dilakukan. Pusat kegiatan ini adalah di rumah adat milik keluarga wanita. Saat pernikahan akan dilangsungkan, masing-masing calon pengantin akan datang bersama kerabat dan saling bertemu di depan pintu masuk gereja. Ketika itu, maka orang tua pria akan bertemu dengan orang tua wanita baru pertama kali. Prosesi selanjutnya mengikuti rangkaian pemberkatan pernikahan di gereja. Setelah selesai acara 
pemberkatan, keluarga pria menuju ke rumah pihak wanita yaitu tempat dilangsungkannya resepsi pernikahan. Saat itu pihak keluarga wanita melangsungkan acara Toli Towa yang berarti seluruh keluarga wanita mengantar ke hadapan pengantin dengan jabat tangan dengan memakai kain tenun khas. Maknanya adalah keluarga wanita secara resmi melepaskan anak mereka untuk bergabung dengan suaminya.

Berikutnya, setelah resepsi adalah masuk ke ruang yang lebih privat atau dhembi (berfungsi sebagai kamar pengantin). Saat itu, dilaksanakan pido kulambu yaitu pria memberikan penghargaan sejumlah uang kepada empat wanita dari keluarga wanita. Tidak diperbolehkan bagi pengantin untuk keluar rumah dalam waktu empat hari empat malam, dan harus tetap tinggal di rumah. Adapun ruang yang dipakai adalah ruang dalam lingkup mikro yaitu rumah adat.

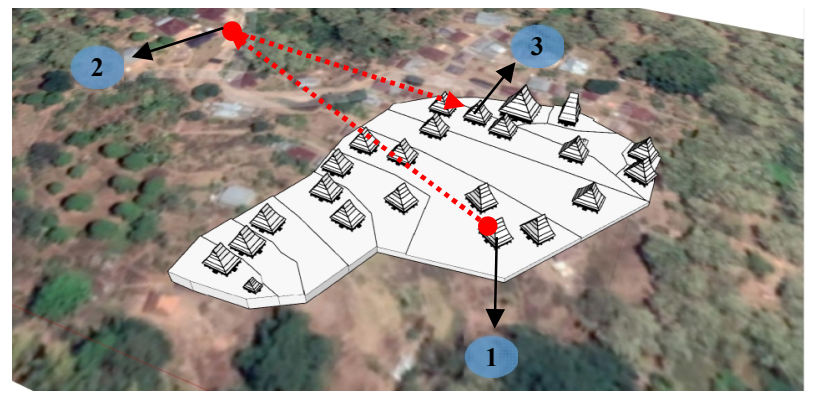

Gambar 7. Pemetaan aktivitas bersama saat kegiatan pernikahan [1] kegiatan menjamu di ruang rumah perempuan, [2] acara pemberkatan di gereja Saga, [3] acara Toli Towa,

[4] pengantin wanita ikut pengantin pria menjalani rumah tangga

\section{3) Hasil Pengamatan Aktivitas Proses Sebelum dan Sesudah Kelahiran}

Masa sebelum melahirkan sudah menjadi tradisi ketika seorang perempuan yang sudah berumah tangga dan ketika hamil, harus dilakukan sesuai dengan adat. Begitu juga saat sudah melahirkan dan anak tersebut beranjak dewasa. Ada beberapa nilai yang bersifat intangible seperti pantangan selama masa kehamilan, seperti (a) tidak diperbolehkan pergi saat malam, namun jika pergi wajib membawa sisir, (b) tidak diperbolehkan menggunting rambut, (c) tidak diperbolehkan makan di atas kasur, (d) tidak diperbolehkan berdiri menghalangi jalan, (e) sebelum makan, pastikan anaknya sudah terurus, dan sebagainya, sedangkan setelah melahirkan contohnya : (a) tidak diperbolehkan membiarkan bayi sendirian tidur di kamar, (b) setiap mandi, harus keramas sampai 40 hari, (c) si ibu tidak boleh makan yang keras dan pedas.

Berdasarkan hasil pengamatan, untuk aktivitas proses sebelum dan sesudah kelahiran tetap menggunakan privat pada ruang rumah adat. Saat setelah menikah, keluarga tinggal rumah adat pihak pria, kemudian masa kehamilan tinggal di koja ndawa (ruang tengah) selama 9 bulan, setelah melahirkan tinggal di dhembi kanan/ kiri. Ruang bersama (publik) berada pada bagian tenda depan dan koja ndawa. (gambar 4 \& 7)
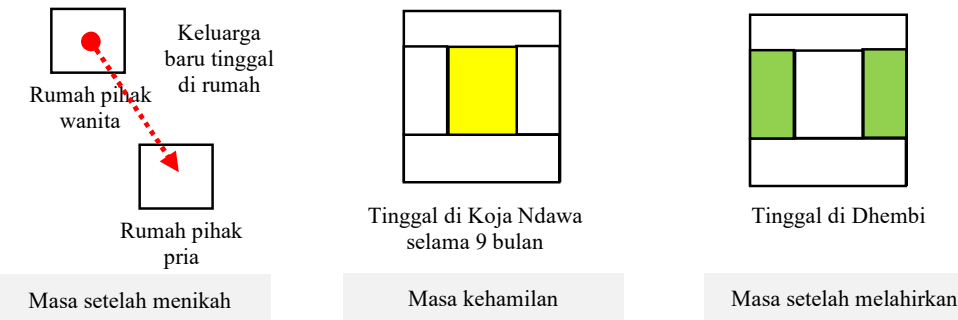

Gambar 8. Pemetaan aktivitas yang terjadi setelah menikah dan memiliki anak 


\section{4) Hasil Pengamatan Aktivitas Upacara Pemakaman}

Aktivitas ini bersifat tidak rutin, hanya saat setelah orang meninggal di rumah adat, baik pagi/siang/sore akan dikuburkan keesokan harinya setelah menghubungi kerabat. Upacara adat pemakaman di Desa Saga merupakan upacara adat turun-temurun dari nenek moyang kepada seluruh masyarakat Desa Saga. Ketika meninggalnya saudara, sebagai saudari mengantarkan berupa hewan ternak seperti babi, kambing, sapi, kuda. Begitupun sebaliknya ketika meninggal saudari, saudara laki laki mengantarkan beras, kain, dan baju adat. Upacara adat ini dibuat dan dipercayai sebagai tanda penghargaan dan penghormatan nyata untuk menciptakan tali kekeluargaan yang erat dan luas.

Upacara adat pemakaman sangat bermakna karena akan terus dikenang sepanjang hidup dan menciptakan tali persaudaraan yang erat. Prosesinya melibatkan beberapa ruang di lingkup makro yaitu rumah adat, rumah duka, tubu musu, dan pemakaman. Setelah yang bersangkutan meninggal, jenazah dibawa ke rumah duka kemudian dibawa ke rumah adat, upacara dilangsungkan di tubu musu dan terakhir dimakamkan di depan rumah adat masing-masing. Perlu diketahui bahwa setiap sekitar rumah adat terdapat batu ceper yang berfungsi sebagai makam leluhur.
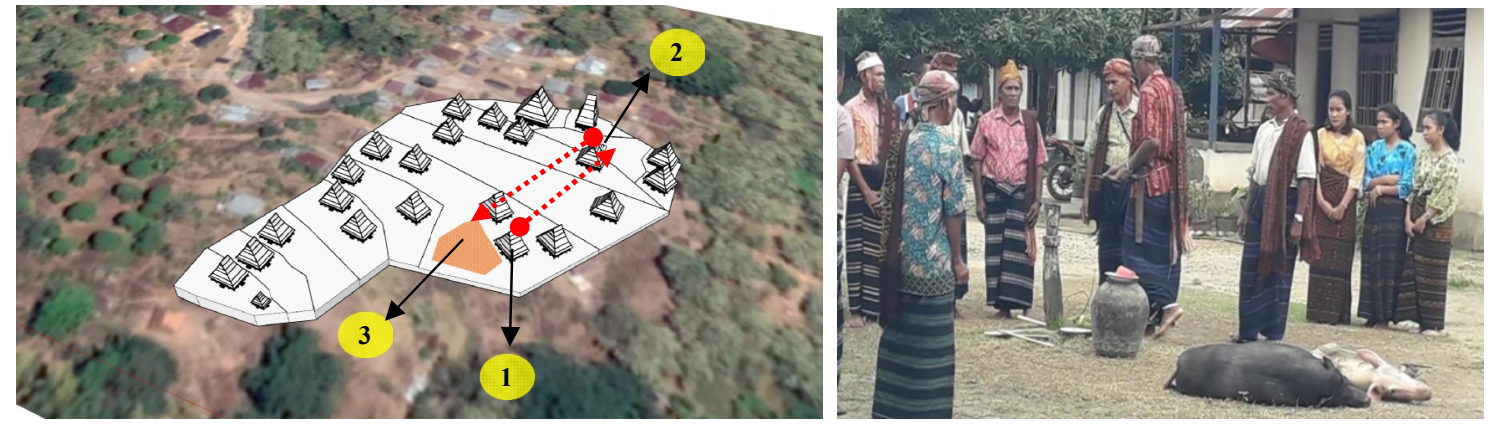

Gambar 9. Pemetaan aktivitas bersama saat upacara adat pemakaman, [1] jenazah dibawa ke rumah duka, [2] kemudian dibawa ke tubu musu untuk dilangsungkan upacara adat, dan [3] jenazah dimakamkan di depan rumah adat

\subsection{Aspek Kesehatan Lingkungan dan Keterkaitannya terhadap Penggunaan Ruang}

Lingkungan yang bersih dan sehat, tidak hanya untuk meningkatkan kesehatan masyarakat, tetapi juga kenyamanan untuk tinggal. Kriteria lingkungan yang sehat dilihat dari keadaan air, udara dan tanah yang tidak tercemar (Budihardjo, 2003).

Pemeliharaan kesehatan lingkungan contohnya adalah menjaga kebersihan. Tidak adanya penyakit dan sampah dikarenakan oleh lingkungan yang sehat. Jika ada sampah organik atau sampah yang mudah terurai maka sebaiknya ditimbun dalam tanah, contohnya daun dan ranting kering, sedangkan sampah anorganik tidak dapat ditimbun biasa karena tidak akan terurai tetapi dengan cara dibakar dahulu, sedangkan sisanya bakal ditimbun.

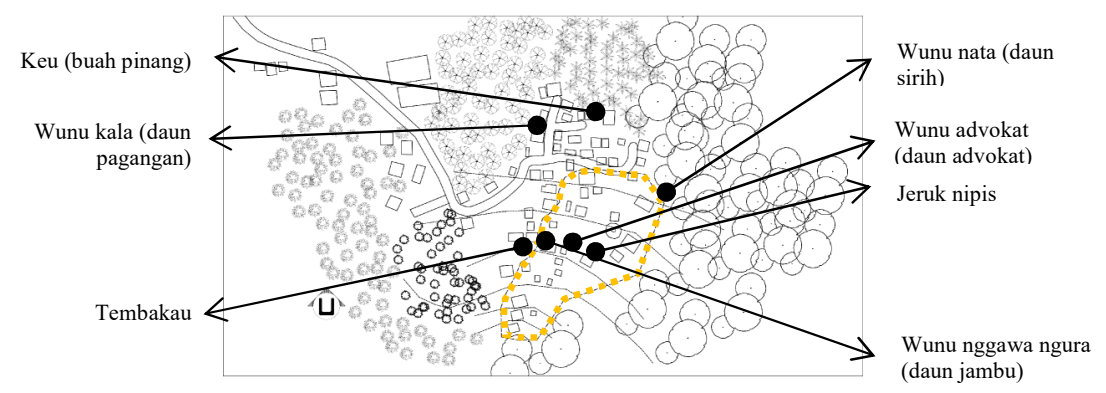

Gambar 10. Peta vegetasi obat alami 
Aspek kesehatan lingkungan sudah memenuhi kriteria sehat dimana pada masyarakat saga tidak ada pencemaran air, udara dan tanah serta faktor-faktor yang dapat menumbulkan penyakit seperti agent/penyebab penyakit dan host/penjamu dapat diminimalkan, walaupun masih ada faktor yang menyebabkan penyakit seperti karakteristik lingkungan yang mana rumah warga yang berlokasi di hutan dan berpotensi penyakit malaria, tetapi kesadaran masyarakat terhadap tenaga kesehatan sudah baik sehingga bila ada warga yang sakit langsung pergi ke pelayanan kesehatan seperti puskesmas. Alternatifnya, masyarakat juga mengatasi masalah kesehatan dengan mencari tumbuhan berkhasiat sebagai obat yang berada di sekitar permukiman. Pemanfaatan obat tradisional ini sudah dilakukan secara turun temurun dan cara pengambilannya pun seperti biasa/tidak ada tradisi khusus, contohnya (1) tanaman Pepaya (Carica papaya L.). Kandungan daunnya terdiri atas alkaloida, saponin, flavoida dan polifenol yang dapat digunakan untuk pengobatan malaria, (2) jeruk nipis (Citrus aurantiifolia) yang mengandung minyak atsiri dan mampu mengendalikan otot pernapasan sehingga batuk menjadi reda, (3) jambu biji (Psidium guajava L.) didalamnya terkandung tanin yang dapat mengatasi masalah diare, serta alpukat (Persea americana Mill.) yang mengandung potasium dan kalium yang dapat mengurangi tekanan darah, depresi dan mencegah pengendapan cairan tubuh. Sehingga dapat dikatakan bahwa kesadaran masyarakat akan kesehatan sudah tinggi didukung oleh fasilitas kesehatan di sekitar permukiman dan upaya penyediaan tanaman obat di sekitar permukiman.

Selain untuk obat, beberapa tanaman berperan untuk upacara adat, baik panen dan tanam padi, pernikahan, dan pemakaman yaitu daun sirih, biji pinang, dan tembakau. Saat upacara adat, mosalaki memberikan jamuan kepada nenek moyang. Daun sirih dan biji pinang untuk kaum wanita sedangkan tembakau untuk kaum pria.

Keterkaitan penggunaan ruang dan kesehatan lingkungan di desa Saga sebagai berikut. Umumnya rumah tradisional dibangun mengikuti kontur dan massa yang terpisah, berbeda dengan rumah modern saat ini, karena lahan masih cukup luas dan warga setempat belum banyak. Lingkungan binaan ini membentuk sistem pasif yang menyehatkan seperti tidak ada halangan sinar matahari dan aliran angin masuk ke dalam rumah. Namun ada keterbatasan yaitu tidak adanya tanaman peneduh seperti pohon di sekitar rumah adat karena hal ini dilarang. Rumah adat dekat dengan makam keluarga, sehingga pohon dapat menghalangi. Akibatnya, suhu sekitar rumah saat siang hari cukup panas pada musim kemarau. Selain itu, aliran udara juga berkaitan dengan kesehatan, posisi rumah besar (komunal) aliran udaranya lebih bebas daripada rumah adat biasa.

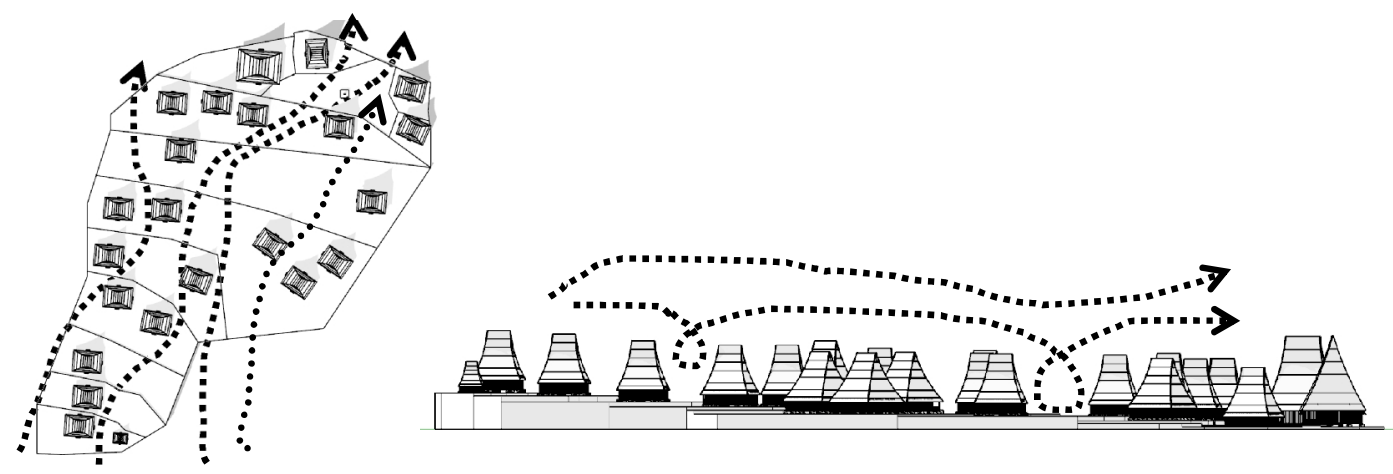

Gambar 11. Pola massa bangunan, kontur, dan ilustrasi arah angin di desa adat Saga 


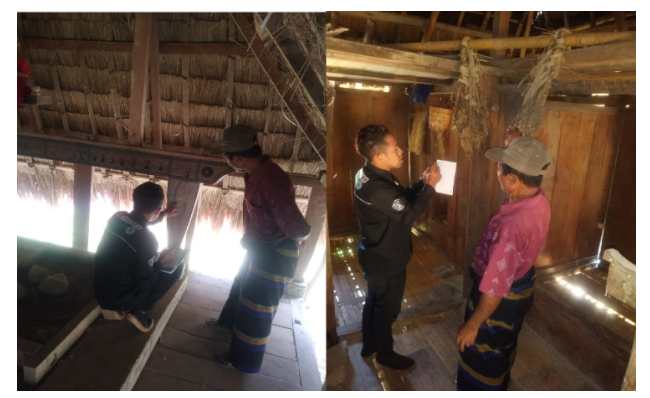

Gambar 12. Terlihat adanya bukaan untuk aliran udara masuk pada rumah besar (kiri), interior rumah adat biasa cukup rapat (kanan)

\section{Simpulan}

Ruang merupakan tempat melakukan aktivitas bagi manusia. Dari lingkup sederhana ruang yang diciptakan oleh manusia adalah rumah tinggal, sedangkan lingkup lebih luas adalah manusia dalam hubungannya dengan lingkungan sekitar dan sosial. Kajian ini membahas tentang penggunaan ruang bagi masyarakat di desa adat Saga dengan mengidentifikasi kembali bentuk dan ruang rumah adatnya dengan melanjutkan penelitian sebelumnya. Pentingnya kajian ini dilakukan adalah untuk mengenali ruang dan hubungan penggunaannya untuk tradisi di masyarakat seperti daur hidup (kelahiran, pemakaman, pernikahan dan pertanian) yang dapat dilihat pada pemetaan aktivitas sosial. Aspek lainnya yang juga dibahas adalah mengenai keterkaitan ruang terhadap kesehatan lingkungan. Tanaman yang tersedia di sekitar rumah selain berfungsi untuk obat juga untuk ritual tertentu. Potensi ruang juga berhubungan dengan kesehatan lingkungan seperti tata massa rumah dan aliran bukaannya.

\section{Daftar Pustaka}

Achmad, Z. H., Antariksa, dan Nugroho, A. M. (2017). Kosmologi Ruang Vertikal dan Horizontal pada Rumah Tradisional (Sa'o) Desa Adat Saga, Kabupaten Ende, Flores. Jurnal Teknik Arsitektur ARTEKS. 1 (2): 171-184

Said, A.A. (2004). Toraja Simbolisme Unsur Visual Rumah Tradisional. Yogyakarta: Ombak.

Budihardjo, E. (2003). Kota dan Lingkungan, United Nation, University Pers Jakarta: LP3ES.

Ching, F. D. (2014). Architecture: Form, space, and order (fourth edition). John Wiley \& Sons.

Creswell, J. W., \& Poth, C. N. (2016). Qualitative inquiry and research design: Choosing among five approaches (fourth edition). Sage publications.

De Rosary, E. (2016). Inilah Kampung Adat Saga dengan Arsitektur Rumah dan Budayanya yang Unik. (Online). https://www.mongabay.co.id/2016/10/05/inilahkampung-adat-saga-dengan-arsitektur-rumah-adat-dan-budayanya-yang-unik/. Diakses 11 Maret 2020.

Fitriyani, I., Antariksa, A., \& Wulandari, L. D. (2015). Penggunaan Ruang Pada Usaha Batik Tulis Di Kampung Batik Jetis Sidoarjo. RUAS (Review of Urbanism and Architectural Studies), 13(2), 47-59.

Indeswari, A., Antariksa, A., Pangarsa, G. W., \& Wulandari, L. D. (2013). Pola Ruang Bersama pada Permukiman Madura Medalungan di Dusun Baran Randugading. RUAS (Review of Urbanism and Architectural Studies), 11(1), 37-46.

Koentjoroningrat. (2004). Kebudayaan, Mentalitas dan Pembangunan. Jakarta: Gramedia Pustaka Utama, hlm. 9 
Paramita, A., \& Kristiana, L. (2013). Teknik Focus Group Discussion Dalam Penelitian Kualitatif. Buletin Penelitian Sistem Kesehatan, 16(2), 20840.

Prijotomo, J. dan Pangarsa, G.W. (2010) Rong: Wacana Ruang Arsitektur Jawa. Ebook Engine. (www.ruangarsitektur.com, diakses 12 Maret 2020)

Pramono, A. (2017). Media Pendukung Pembelajaran Rumah Adat Indonesia Menggunakan Augmented Reality. Jurnal Eltek, 11(1), 122-132. 